\title{
Penggunaan Bakteriosin yang Diproduksi oleh Lactobacillus plantarum sebagai Pengawet Alami untuk Daging Ayam yang Disimpan di Suhu Ruang
}

\author{
The Use of Bacteriocins Produced by Lactobacillus plantarum as Natural Preservative for Chicken Meats \\ were Stored at Room Temperature
}

Y. Nurraifah, I. I. Arief', \& N. Ulupi

Department of Animal Production and Technology, Faculty of Animal Science, IPB University

Jl. Agatis, Kampus IPB Darmaga Bogor 16680,

*Corresponding author: isnafia@apps.ipb.ac.id

(Received 30-10-2020; Revised 30-11-2020; Accepted 25-12-2020)

\begin{abstract}
Bacteriocins is a natural preservative (bio-preservatives) that can safely be used for food. Bacteriocins can be produced by a group of Lactic Acid Bacteria (LAB). Several strains of lactic acid bacteria (LAB) is bactericidal against gram positive and gram negative bacteria. The purpose of this study was to analyze the bacteriocins produced by Lactobacillus plantarum in chicken meat and determine the level of the last and long-term. Factors that are seen in this study is the levels of bacteriocins and also the duration of storage of chicken meat. The levels of bacteriocins is $0 \%$ and $10 \%$ by way of spraying in chicken meat and duration of storage are at $0,5,10,15,20$, and 25 hours at room temperature. This study used a factorial completely randomized design with three replications. Plantaricin concentration against $\mathrm{pH}$ and $\mathrm{a}_{\mathrm{w}}$ values were significantly different $(\mathrm{P}<0.05)$. The test result of storage duration against water content were significantly different $(P<0.05)$. Treatment of plantarisin IIA-1A5 $10 \%$ to maintain the condition of chicken meat was better than treatment without the adding plantarisin.
\end{abstract}

Keywords: bacteriocins, natural preservative, chicken meat

\section{ABSTRAK}

Bakteriosin merupakan bahan pengawet alami yang aman digunakan untuk makanan. Bakteriosin dapat diproduksi oleh bakteri asam laktat (BAL) dan dapat menjadi bahan bakterisidal gram positif dan gram negatif. Tujuan dari penelitian ini adalah untuk menganalisis efek pemberian pengawet alami yaitu bakteriosin yang diproduksi oleh Lactobacillus plantarum pada daging dada ayam dengan perlakuan perbedaan taraf bakteriosin dan lama penyimpanan. Taraf bakteriosin yang yang digunakan adalah $0 \%$ dan $10 \%$ dengan metode spray pada lama penyimpanan $0,5,10,15,20$, dan 25 pada suhu ruang. Analisis data yang digunakan pada penelitian ini dengan menggunakan rancangan acak lengkap pola faktorial dengan menggunakan 3 kali pengulangan. Hasil pengujian konsentrasi plantarisin terhadap nilai $\mathrm{pH}$ dan $\mathrm{a}_{\mathrm{w}}$ berbeda nyata $(\mathrm{P}<0.05)$. Hasil pengujian lama penyimpanan terhadap kadar air berbeda nyata $(\mathbf{P}<\mathbf{0 . 0 5})$. Perlakuan plantarisin IIA-1A5 10\% mampu mempertahankan kondisi daging ayam lebih baik dibandingkan perlakuan tanpa penambahan plantarisin.

Kata kunci: bakteriosin, pengawet alami, daging ayam

\section{PENDAHULUAN}

Bahan pengawet kimia untuk makanan dapat memperpanjang umur simpan makanan. Konsumsi bahan pengawet kimia yang berlebihan dapat mengganggu kesehatan tubuh dan menjadi residu pada tubuh. Residu bahan kimia yang tertinggal di dalam tubuh dapat memicu timbulnya berbagai macam penyakit diantaranya kanker. Untuk mengatasi hal tersebut maka pemanfaatan bahan pengawet alami (biopreservasi) sangat potensial untuk diaplikasikan dalam pengawetan pangan karena dapat mengontrol pertumbuhan bakteri patogen secara alami dan aman (Mataragas et al. 2003). Pemanfaatan bahan pengawet alami salah satunya yaitu dapat menggunakan bakteriosin. 
Bakteriosin dapat digunakan sebagai agen biopreservatif karena mampu mencegah pembusukan pangan dengan menghambat pertumbuhan bakteri patogen. Bakteriosin dapat diproduksi oleh kelompok bakteri asam laktat (BAL), beberapa galur bakteri asam laktat (BAL) dapat menghasilkan senyawa protein yang disebut bakteriosin, dan bersifat bakterisidal terhadap bakteri gram positif dan gram negatif (Tahara et al. 1996).

Beberapa kelebihan bakteriosin sehingga potensial digunakan sebagai biopreservatif yaitu: (i) bukan bahan toksik dan mudah mengalami degradasi oleh enzim proteolitik karena merupakan senyawa protein; (ii) tidak membahayakan mikroflora usus karena mudah dicerna oleh enzim saluran pencernaan; (iii) dapat mengurangi penggunaan bahan kimia sebagai pengawet pangan; (iv) penggunaannya fleksibel; dan (v) stabil terhadap $\mathrm{pH}$ dan suhu sehingga tahan terhadap proses pengolahan yang melibatkan asam dan basa, serta kondisi panas dan dingin (Cleveland et al. 2001). Bakteri patogen penyebab kebusukan yang banyak dijumpai pada daging mentah antara lain Escherichia coli, Salmonella sp, dan Listeria monocytogenes (Usmiati dan Marwati 2007).

Bakteriosin merupakan senyawa peptida yang dapat digunakan sebagai bahan pengawet alami memiliki potensi untuk mencegah berkembangnya bakteri patogen daging mentah. Daging ayam yang disimpan pada suhu kamar pada waktu tertentu akan mengalami kerusakan. Hal ini karena daging ayam merupakan bahan pangan yang bergizi tinggi dan media yang baik untuk pertumbuhan mikroba. Kerusakan daging ayam oleh mikroba mengakibatkan penurunan mutu daging ayam.

Penurunan mutu daging ayam salah satunya dapat dilihat dari jumlah cemaran mikroba yang terbentuk. Jumlah dan jenis mikroba yang mencemari permukaan daging ayam ditentukan oleh penanganan sebelum penyembelihan ternak dan tingkat pengendalian higienis dan sistem sanitasi yang baik selama penanganan hingga dikonsumsi. Besarnya kontaminasi mikroba pada daging menentukan kualitas dan masa simpan daging ayam. Daging perlu diawetkan untuk menghindari kerusakan dengan memperhatikan persyaratan keamanan pangan (Usmiati 2010).

\section{MATERI DAN METODE}

\section{Waktu dan Lokasi Penelitian}

Penelitian dilakukan di Laboratorium Terpadu Fakultas Peternakan Divisi Teknologi Hasil Ternak, Institut Pertanian Bogor. Penelitian berlangsung mulai Januari hingga Maret 2017.

\section{Prosedur}

Produksi bakteriosin dilakukan dengan proses pemurnian bakteriosin kasar dari L. plantarum IIA-1A5 melalui tahapan purifikasi dengan ammonium sulfat dan dialisis. Bakteriosin kasar hasil dialysis masih berupa bakteriosin pekat sehingga dalam penggunaannya diencerkan dengan menggunakan akuades dengan perbandingan 1:10 (v/v). Pemberian level bakteriosin kasar yang telah diencerkan tersebut adalah sebesar $0 \%$ dan $10 \%$ dari bobot daging dada ayam.
Daging ayam bagian dada disiapkan sebanyak 36 potong. Sebanyak 18 potong daging dada ayam disemprotkan menggunakan $10 \%$ bakteriosin pada semua sisi dada ayam dan tunggu selama 30 menit sampai bakteriosin meresap pada daging ayam. Langkah selanjutnya melakukan pengamatan selama $0,5,10,15,20$, dan 25 jam pada suhu ruang yaitu $25-27^{\circ} \mathrm{C}$.

\section{Uji Tantang Plantarisin IIA-1A5 terhadap Bakteri Patogen}

Untuk menguji aktivotas antimikrba bakteriosin kasar maka dilakukan uji penghambatan terhadap bakteri pathogen (uji tantang). Bakteri patogen yang digunakan dalam penelitian ini adalah Pseudomonas aeruginosa dan Staphylococcus aureus. Bakteri ini diremajakan sebanyak 2 kali. Selanjutnya diinokulasi ke dalam media $\mathrm{NaCl} 0.85 \%$ hingga mencapai konsentrasi $108 \mathrm{cfu} \mathrm{mL}^{-1}$ (dibandingkan dengan larutan standar Mc.Farland). Kultur dipipet sebanyak $1 \mathrm{~mL}$ ke $9 \mathrm{~mL} \mathrm{NaCl} 0.85 \%$ sehingga konsentrasinya menjadi $107 \mathrm{cfu} \mathrm{mL}^{-1}$. Pengenceran yang sama dilakukan kembali sehingga diperoleh konsentrasi bakteri $106 \mathrm{cfu} \mathrm{mL}^{-1}$. Media mueller hinton agar (MHA) sebanyak $20 \mathrm{~mL}$ dituangkan ke dalam cawan petri steril selama 10 menit hingga mengeras dan kemudian $100 \mu \mathrm{L}$ bakteri patogen disebarkan pada permukaan media MHA.

Bakteriosin kasar diteteskan pada paper disc steril sebanyak $50 \mu \mathrm{L}$ dari masing-masing konsentrasi protein $(1.56 \%, 3.13 \%, 6.25 \%$ 12.50\%, 25.00\%, dan 50.00\%) dan ditunggu selama 30 menit. Paper disc steril diletakan di atas permukaan media MHA yang telah diinokulasi oleh bakteri patogen. Setelah itu cawan diletakkan pada refrigerator dengan suhu $3{ }^{\circ} \mathrm{C}$ selama 3 jam dan ditutup dengan kertas saring. Cawan tersebut selanjutnya diinkubasi pada inkubator selama 24 jam pada suhu $37^{\circ} \mathrm{C}$. Aktivitas antimikrob bakteriosin ditandai dengan terbentuknya zona bening di sekitar paper disc dan diukur diameternya (Kanmani et al. 2010).

\section{Analisis Total Plate Count (Bacteriological Analitycal Manual 2001)}

Sebanyak $25 \mathrm{~g}$ sampel daging ayam ditimbang secara aseptic, kemudian sampel dihomogenisasi menggunakan blender dengan penambahan $225 \mathrm{~mL}$ larutan buffer peptone water (BPW) sehingga diperoleh pengenceran 101. Larutan tersebut dipindahkan sebanyak $1 \mathrm{~mL}$ secara aseptik ke dalam tabung reaksi yang berisi $9 \mathrm{~mL}$ larutan buffer pepton water (BPW) sehingga diperoleh pengenceran 102, perlakuan yang sama dilakukan sampai ke pengenceran 103 .

Selanjutnya sebanyak $1 \mathrm{~mL}$ larutan pada masingmasing pengenceran 101, 102, dan 103 secara duplo dipindahkan ke dalam cawan yang telah disterilkan sebelumnya. Larutan media plate count agar (PCA) bersuhu $40{ }^{\circ} \mathrm{C}$ sebanyak $15-20 \mathrm{~mL}$ ditambahkan ke dalam cawan petri dan dibiarkan selama 5 menit hingga larutan mengeras. Cawan petri diinkubasi dalam inkubator pada suhu $37{ }^{\circ} \mathrm{C}$ selama 24 jam dan hitung jumlah koloni yang terbentuk dengan rumus sebagai berikut : 


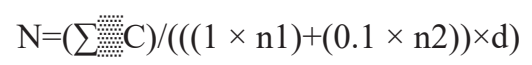

Keterangan :

$$
\begin{array}{ll}
\mathrm{N} & =\text { Jumlah koloni per mL produk; } \\
\Sigma \mathrm{C} & =\text { Jumlah semua koloni yang dihitung pada semua } \\
& \quad \text { cawan petri; } \\
\mathrm{n} 1 & =\text { Jumlah cawan petri yang dihitung pada } \\
& \text { pengenceran pertama; } \\
\mathrm{n} 2 \quad & \text { Jumlah cawan petri yang dihitung pada } \\
& \text { pengenceran kedua; dan } \\
\mathrm{d} \quad & \text { Pengenceran dimana cawan petri pertama } \\
& \text { dihitung }
\end{array}
$$

\section{Uji Fisikokimia Daging Ayam}

Nilai pH (AOAC 1984). Sebanyak $10 \mathrm{~g}$ sampel daging dada ayam dipotong memanjang, kemudian ditusuk dengan menggunakan $\mathrm{pH}$ meter yang sebelumnya dikalibrasi pada $\mathrm{pH} 4$ dan 7.

Nilai Aktivitas Air (AOAC 1984). Penentuan nilai aktivitas air dari produk diukur dengan menggunakan alat pengukur $\mathrm{a}_{\mathrm{w}}$ (Shibaura $\mathrm{a}_{\mathrm{w}}$ meter). Alat dikalibrasi dengan cara garam dimasukkan ke dalam wadah yang telah tersedia dan dilakukan pengukuran $\mathrm{a}_{\mathrm{w}}$ produk.

Jenis garam yang digunakan adalah $\mathrm{BaCl}_{2}$, $\mathrm{Mg}\left(\mathrm{NO}_{3}\right)_{2}, \mathrm{NaCl}$, dan $\mathrm{KCl}$. Sampel dimasukan ke dalam wadah yang tersedia pada alat tersebut kemudian sampel didiamkan kurang lebih 15 menit, setelah itu dilihat nilai aw yang tertera pada alat tersebut.

Kadar air (AOAC 2005). Kadar air ditentukan dengan metode oven. Sampel daging ayam dimasukkan sebanyak $10 \mathrm{~g}$ ke dalam cawan porselen yang telah diketahui bobotnya. Sampel dan cawan tersebut dioven selama 18 jam pada suhu $105^{\circ} \mathrm{C}$, setelah itu sampel didinginkan di dalam desikator. Setelah 30 menit sampel dan cawan ditimbang sampai diperoleh berat konstan. Kadar air dapat dihitung dengan menggunakan rumus sebagai berikut :

Kadar Air $(\%)=(($ bobot awal-bobot akhir $)) /($ bobot awal $)$ $\times 100 \%$

\section{Pengujian Mutu Organoleptik Metode Rating Test (Lawless dan Heymann 2010)}

Uji mutu hedonik dilakukan untuk menilai daya terima dan kualitas produk pangan dengan metode rating test menggunakan 5 interval nilai. Parameter yang dinilai meliputi warna (sangat pucat, pucat, agak pucat (putih), agak cerah merah, cerah kemerahan), intensitas aroma daging dada ayam (sangat amis, amis, agak amis, tidak amis, dan aroma khas daging) dan intensitas lendir (sangat berlendir, berlendir, agak berlendir, tidak berlendir, dan sangat tidak berlendir).

Pengujian mutu organoleptik tiap kombinasi perlakuan dilakukan secara bersamaan. Pengujian dilakukan terhadap 40 orang panelis semi terlatih. Berdasarkan pengujian mutu hedonik organoleptik ini diketahui perlakuan yang terbaik yaitu masih diterima oleh panelis dan kelayakan daging untuk dikonsumsi.

\section{Analisis Data}

Penelitian ini menggunakan 3 rancangan. Pertama menggunakan rancangan acak lengkap (RAL) untuk menganalisis zona hambat bakteri patogen. Kedua menggunakan rancangan acak lengkap (RAL) pola faktorial untuk menganalisis TPC, pH, kadar air, dan aktivitas air. Faktor perlakuan yang pertama adalah konsentrasi plantarisin sebesar $0 \%$ dan $10 \%$. Faktor perlakuan yang kedua adalah lama penyimpanan pada jam ke-0, 5, 10, 15, 20, dan 25. Pengulangan pada penelitian ini dilakukan sebanyak 3 kali. Data yang diperoleh dianalisa dengan menggunakan analisis ragam ANOVA untuk mengetahui pengaruh dari perlakuan. Jika perlakuan berpengaruh nyata atau sangat nyata, dilakukan uji banding berganda Tukey (Steel dan Torrie 1995). Model sistematika rancangan acak lengkap faktorial menurut Steel dan Torie (1995) sebagai berikut :

$$
Y i j k=\mu+P i+Y j+P Y i j+€ i j k
$$

Keterangan:

Yijk = Variabel respon akibat pengaruh pemberian konsentrasi bakeriosin ke-i, lama penyimpanan ke-j pada ulangan ke-k;

$\mu \quad=$ Nilai tengah umum;

$\mathrm{Pi}=$ Pengaruh konsentrasi bakteriosin ke-i $(\mathrm{i}=0 \%$ dan $10 \%$ );

$\mathrm{Yj} \quad=$ Pengaruh lama penyimpanan ke-j $(\mathrm{j}=0 \mathrm{jam}, 5$ jam, 10 jam, 15 jam, 20 jam, dan 25 jam);

Pyij = Pengaruh interaksi antara pemberian konsentrasi bakeriosin ke-i dengan lama penyimpanan ke-j;

$€ \mathrm{ij} \quad=$ Pengaruh galat perlakuan ke-i dan ke-j terhadap ulangan ke-k. $\mathrm{k}=1,2$, dan 3 .

\section{HASIL DAN PEMBAHASAN}

\section{Karakteristik Bakteri Pseudomonas aeruginosa dan Staphylococcus aureus}

Bakteri Pseudomonas aeruginosa dan Staphylococcus aureus termasuk ke dalam bakteri patogen yang dapat menyebabkan penyakit pada manusia. Kedua bakteri ini dapat mencemari makanan diantaranya adalah daging ayam. Bakteri Pseudomonas aeruginosa memiliki karakteristik yaitu merupakan gram negatif, berbentuk batang atau kokus serta motil karena mempunyai flagel polar. Bakteri ini merupakan bakteri nonfermenter dan tumbuh dengan baik pada suhu $4{ }^{\circ} \mathrm{C}$ atau dibawah $43{ }^{\circ} \mathrm{C}$ (Suyono 2011). Pseudomonas dapat menimbulkan penyakit yaitu infeksi pada luka dan luka bakar menimbulkan nanah hijau kebiruan, infeksi saluran kemih, infeksi pada saluran napas mengakibatkan pneumonia yang disertai nekrosis, otitis eksterna ringan pada perenang, dan infeksi mata.

Staphylococcus aureus merupakan bakteri gram positif berbentuk bulat berdiameter 0.7-1.2 $\mu \mathrm{m}$. Bakteri ini tumbuh pada suhu optimum $37{ }^{\circ} \mathrm{C}$, tetapi membentuk pigmen paling baik pada suhu kamar $\left(20-25^{\circ} \mathrm{C}\right)$. Lebih dari $90 \%$ isolat klinik menghasilkan $S$. aureus yang mempunyai kapsul polisakarida atau selaput tipis yang berperan dalam virulensi bakteri (Jawetz et al. 1995). S. aureus juga 
merupakan penyebab utama infeksi nosocomial, keracunan makanan, dan sindroma syok toksik (Ryan et al.1994; Warsa 1994). Gejala keracunan ditandai oleh rasa mual, muntahmuntah, dan diare yang hebat tanpa disertai demam (Ryan et al. 1994 ; Jawetz et al. 1995).

\section{Aktivitas Antimikrob Bakteriosin Kasar}

Bakteriosin memiliki beberapa fungsi diantaranya dapat menjadi bahan pengawet alami dan menghambat pertumbuhan bakteri patogen. Bakteriosin dapat menghambat aktivitas antimikroba terhadap bakteri patogen meliputi Pseudomonas aeruginosa dan Staphylococcus aureus (Arief 2011). Plantarisin IIA-1A5 merupakan senyawa protein bakteriosin yang diproduksi oleh Lactobacillus plantarum IIA-1A5 (Arief et al. 2015).

Tabel 1. Diameter zona hambat bakteriosin terhadap bakteri patogen

\begin{tabular}{|c|c|c|}
\hline \multirow{2}{*}{$\begin{array}{c}\text { Konsentrasi } \\
\text { bakteriosin (\%) }\end{array}$} & \multicolumn{2}{|c|}{ Diameter zona hambat (mm) } \\
\hline & $\begin{array}{c}\text { Pseudomonas } \\
\text { aeruginosa }\end{array}$ & $\begin{array}{c}\text { Staphylococcus } \\
\text { aureus }\end{array}$ \\
\hline 1.56 & $8.50 \pm 0.81 \mathrm{a}$ & $8.54 \pm 1.13$ \\
\hline 3.13 & $9.39 \pm 0.36 \mathrm{ab}$ & $8.80 \pm 2.04$ \\
\hline 6.25 & $9.76 \pm 0.35 \mathrm{ab}$ & $9.29 \pm 1.33$ \\
\hline 12.5 & $10.06 \pm 0.65 \mathrm{ab}$ & $9.88 \pm 1.20$ \\
\hline 25 & $10.42 \pm 0.23 \mathrm{ab}$ & $10.07 \pm 1.31$ \\
\hline 50 & $10.87 \pm 0.56 b$ & $10.26 \pm 1.30$ \\
\hline
\end{tabular}

Angka disertai huruf berbeda pada kolom yang sama menunjukkan perbedaan nyata $(\mathrm{P}<0.05)$.

Hasil analisis ragam menunjukkan bahwa terdapat perbedaan nyata pada diameter zona hambat Pseudomonas aeruginosa pada masing-masing konsentrasi bakteriosin $(\mathrm{P}<0.05)$ (Tabel 1). Hasil analisis ragam menunjukkan bahwa tidak terdapat perbedaan nyata pada diameter zona hambat Staphylococcus aureus pada masing-masing konsentrasi plantarisin $(\mathrm{P}>0.05)$. Bakteriosin kasar mampu menghambat pertumbuhan bakteri patogen Pseudomonas aeruginosa dan Staphylococcus aureus. Plantarisin dan nisin merupakan pengawet makanan alami yang berasal dari bakteri asam laktat (Delves 2005). Konsentrasi penggunaan bakteriosin plantarisin sebagai bahan pengawet pada penelitian ini adalah $6.25 \%$ dari $10 \%$ berat daging ayam atau setara dengan $1.6 \mathrm{mg} \mathrm{kg}^{-1}$. Penggunaan bahan pengawet tergolong aman karena lebih rendah dari batasan penggunaan bahan pengawet dari nisin yaitu $12.5 \mathrm{mg} \mathrm{kg}^{-1}$ (BPOM 2013). Diameter zona hambat pada konsentrasi plantarisin $6.25 \%$ tidak berbeda dengan konsentrasi plantarisin pada 50\%. Hal ini membuktikan bahwa bakteriosin dari L.plantarum IIA-1A5 pada konsentrasi $6.25 \%$ berpotensi sebagai bahan pengawet alami karena dapat menghambat bakteri patogen. Penggunaan konsentrasi bakteriosin dari L.plantarum IIA-1A5 sebesar 6.25\% memiliki diameter zona hambat terhadap bakteri Pseudomonas aeruginosa dan Staphylococcus aureus sebesar 9.76 \pm 0.35 dan $9.29 \pm 1.33$.

Beberapa strain Lactobacillus plantarum yang memproduksi bakteriosin dan dapat menghambat bakteri gram negatif telah dilaporkan. Lactobacillus plantarum
ST202Ch dan Lactobacillus plantarum ST216Ch memproduksi bakteriosin yang memiliki 9 aktivitas antimikroba terhadap bakteri gram positif dan gram negatif (Todorov dan Dicks 2005). Plantarisin yang diproduksi oleh bakteri gram positif yang dapat menghambat bakteri gram negatif dan juga gram positif (Todorov et al. 2007).

\section{Analisis Total Plate Count}

Total plate count merupakan metode penghitungan sel tampak dan didasarkan pada asumsi bahwa bakteri hidup akan tumbuh, membelah, dan memproduksi 1 koloni tunggal. Metode pengukuran ini dilakukan pada plate dengan jumlah koloni berkisar 25-250 atau 30-300 (Pratiwi 2008). Perhitungan mikroba dilakukan pada daging dada ayam yang diberikan perlakuan konsentrasi plantarisin IIA1A5 $0 \%$ dan $10 \%$ dengan lama penyimpanan pada jam ke- 0 , 5, 10, 15, 20, dan 25. Rataan cemaran mikroba disajikan pada Tabel 2 .

Tabel 2. Nilai rataan analisis cemaran mikroba $\left(\log 10 \mathrm{cfu} \mathrm{g}^{-1}\right)$ daging ayam pada suhu ruang

\begin{tabular}{ccc}
\hline Lama & \multicolumn{2}{c}{ Konsentrasi Bakteriosin } \\
\cline { 2 - 3 } $\begin{array}{c}\text { Penyimpanan } \\
\text { (jam) }\end{array}$ & $0 \%$ & $10 \%$ \\
\hline 0 & $6.30 \pm 0.28 \mathrm{~d}$ & $5.85 \pm 0.30 \mathrm{~cd}$ \\
5 & $6.47 \pm 0.05 \mathrm{~cd}$ & $6.33 \pm 0.08 \mathrm{~cd}$ \\
10 & $7.08 \pm 0.88 \mathrm{bc}$ & $6.39 \pm 0.26 \mathrm{~cd}$ \\
15 & $7.14 \pm 0.92 \mathrm{bc}$ & $6.44 \pm 0.06 \mathrm{~cd}$ \\
20 & $8.68 \pm 0.03 \mathrm{a}$ & $6.78 \pm 0.17 \mathrm{bcd}$ \\
25 & $8.68 \pm 0.01 \mathrm{a}$ & $7.66 \pm 0.15 \mathrm{ab}$ \\
\hline
\end{tabular}

Angka disertai huruf berbeda pada kolom dan baris yang sama menunjukkan perbedaan nyata $(\mathrm{P}<0.05)$.

Hasil analisis ragam menunjukkan bahwa terdapat perbedaan interaksi yang nyata antara penggunaan bakteriosin $10 \%$ dan kontrol serta perbedaaan lama penyimpanan terhadap daging dada ayam $(\mathrm{P}<0.05)$. Ambang batas maksimum cemaran mikroba pada daging ayam yaitu 1x106 cfu g-1 (SNI 2009). Perlakuan bakteriosin 10\% mampu mempertahankan kualitas daging dada ayam segar pada ambang batas maksimum cemaran mikroba hingga jam ke-20. Perlakuan bakteriosin 0\% hanya mampu mempertahankan kualitas daging dada ayam segar pada ambang batas maksimum cemaran hingga jam ke-5. Hal tersebut dapat disebabkan karena bakteriosin merupakan bahan pengawet alami yang bersifat bakterisidal atau bakteriostatik sehingga dapat membunuh atau menghambat berkembangnya mikroba pada daging ayam. Bakteriosin merupakan molekul protein atau peptida ekstraseluler yang mempunyai aksi bakterisidal atau bakteriostatik terhadap bakteri yang mempunyai kekerabatan dekat (Savadogo et al. 2006). Mekanisme antimikroba bakteriosin plantarisin dimulai dengan masuknya ke dalam sel sasarannya dengan cara membentuk pori pada membran sel yang sensitif dan menurunkan potensial atau gradien $\mathrm{pH}$ yang menyebabkan rusaknya material seluler sehingga mampu menghambat pertumbuhan sel target (Ogunbawo et al. 2003; Moll et al. 1999). 


\section{Aplikasi Bakteriosin pada Daging Dada Ayam}

Pengamatan penggunaan bakteriosin plantarisin IIA1A5 $10 \%$ dan $0 \%$ pada daging dada ayam dilaksanakan pada lama penyimpanan yang berbeda dan suhu kamar yaitu berkisar $26-27^{\circ} \mathrm{C}$. Parameter fisikokimia yang diukur yaitu nilai $\mathrm{pH}$, kadar air, dan aktivitas air untuk menentukan kualitas daging dada ayam.

\section{Nilai pH}

Hasil analisis ragam menunjukkan bahwa tidak ada interaksi antara perlakuan pertama yaitu pemberian konsentrasi bakteriosin plantarisin IIA-1A5 10\% dan 0\% dengan perlakuan kedua yaitu lama penyimpanan pada jam ke- $0,5,10,15,20$, dan 25 . Hasil analisis ragam menunjukkan bahwa terdapat perbedaan $\mathrm{pH}$ yang nyata pada perlakuan pertama yaitu penggunaan bakteriosin plantarisin IIA-1A5 10\% dan 0\% terhadap daging dada ayam $(\mathrm{P}<0.05)$. Perbedaan nilai $\mathrm{pH}$ daging diantara bakteriosin plantarisin IIA-1A5 10\% dan $0 \%$ disebabkan aktivitas bakteriosin plantarisin IIA-1A5 sebagai pengawet alami dapat menjaga kestabilan $\mathrm{pH}$ dari daging ayam. Nilai rata-rata $\mathrm{pH}$ pada perlakuan $10 \%$ termasuk dalam kategori normal yaitu pada $\mathrm{pH}$ 6.25. Nilai $\mathrm{pH}$ tersebut hampir sama dengan penelitian Suradi (2008) yang menyatakan bahwa daging ayam broiler dengan pengukuran $\mathrm{pH} 3$ jam setelah pemotongan yaitu 6.2. Nilai rata-rata $\mathrm{pH}$ pada perlakuan $0 \%$ yaitu 6.18 . Nilai pH ini tidak normal karena nilai pH 6.18 lebih rendah dari 6.2 yang berarti adanya kerusakan pada perlakuan $0 \%$. Hal ini sesuai Suradi (2008) yang menyatakan bahwa nilai $\mathrm{pH}$ daging ayam broiler yang mengalami kerusakan akan mengalami penurunan dan lebih rendah dari 6.2. Hasil nilai rataan $\mathrm{pH}$ daging ayam pada suhu ruang disajikan pada Tabel 3 .

Tabel 3. Nilai rataan $\mathrm{pH}$ daging ayam pada suhu ruang

\begin{tabular}{cccc}
\hline $\begin{array}{c}\text { Lama } \\
\text { Penyimpanan } \\
\text { (jam) }\end{array}$ & \multicolumn{2}{c}{ Konsentrasi Plantarisin } & Rata-rata \\
\cline { 2 - 3 } & $0 \%$ & $10 \%$ & \\
\hline 0 & $6.26 \pm 0.09$ & $6.26 \pm 0.05$ & $6.26 \pm 0.07$ \\
5 & $6.26 \pm 0.05$ & $6.23 \pm 0.02$ & $6.25 \pm 0.03$ \\
10 & $6.23 \pm 0.02$ & $6.23 \pm 0.05$ & $6.23 \pm 0.03$ \\
15 & $6.12 \pm 0.12$ & $6.22 \pm 0.08$ & $6.17 \pm 0.20$ \\
20 & $6.12 \pm 0.09$ & $6.24 \pm 0.08$ & $6.18 \pm 0.08$ \\
25 & $6.10 \pm 0.09$ & $6.30 \pm 0.14$ & $6.20 \pm 0.11$ \\
Rata-rata & $6.18 \pm 0.10 \mathrm{~b}$ & $6.25 \pm 0.71 \mathrm{a}$ & \\
\hline Angkann
\end{tabular}

Angka disertai huruf berbeda pada baris yang sama menunjukkan perbedaan nyata $(\mathrm{P}<0.05)$.

Hasil analisis ragam menunjukkan bahwa tidak terdapat perbedaan $\mathrm{pH}$ yang nyata pada perlakuan kedua yaitu lama penyimpanan pada jam ke- $0,5,10,15,20$, dan 25 terhadap daging dada ayam $(\mathrm{P}>0.05)$. Nilai $\mathrm{pH}$ pada jam ke-0 hingga jam ke-20 mengalami penurunan. Penurunan $\mathrm{pH}$ daging ayam broiler karena lama penyimpanan dapat disebabkan adanya reaksi perubahan glikogen dalam daging menjadi asam laktat oleh mikroba yang terkandung dalam daging (Usmiati 2009). Nilai $\mathrm{pH}$ daging dapat mempengaruhi warna, aroma, kelembutan, dan kualitas makanan (Jelenikova et al. 2008).

\section{Kadar Air}

Hasil analisis ragam menunjukkan bahwa tidak ada perbedaan nyata antara interaksi perlakuan pertama pada pemberian konsentrasi bakteriosin plantarisin IIA-1A5 10\% dan $0 \%$ dengan perlakuan kedua yaitu lama penyimpanan pada jam ke-0, 5, 10, 15, 20, dan 25 terhadap kadar air pada daging dada ayam. Hasil analisis ragam menunjukkan bahwa tidak terdapat perbedaan kadar air yang nyata pada perlakuan pertama $(\mathrm{P}<0.05)$. Nilai kadar air pada perlakuan bakteriosin plantarisin $10 \%$ lebih tinggi dibandingkan dengan nilai kadar air bakteriosin plantarisin $0 \%$. Hal ini karena bakteriosin plantarisin $10 \%$ yang disemprotkan terlebih dahulu diencerkan dengan akuades. Air merupakan ikatan kovalen yang terbentuk dari 2 buah atom hidrogen dan sebuah atom oksigen (Winarno 1992). Hasil nilai rataan kadar air daging ayam pada suhu ruang disajikan pada Tabel 4.

Tabel 4. Nilai rataan kadar air daging ayam pada suhu ruang

\begin{tabular}{cccc}
\hline \multirow{2}{*}{$\begin{array}{c}\text { Lama } \\
\text { Penyimpanan } \\
\text { (jam) }\end{array}$} & \multicolumn{2}{c}{ Konsentrasi Bakteriosin } & Rata-rata \\
\cline { 2 - 3 } & & $10 \%$ & \\
\hline 0 & $75.66 \pm 1.98$ & $76.80 \pm 3.00$ & $76.25 \pm 1.26 \mathrm{a}$ \\
5 & $75.38 \pm 1.77$ & $76.37 \pm 2.80$ & $75.87 \pm 1.01 \mathrm{ab}$ \\
10 & $74.15 \pm 1.76$ & $75.81 \pm 2.25$ & $74.97 \pm 1.72 \mathrm{abc}$ \\
15 & $73.46 \pm 1.86$ & $74.65 \pm 1.90$ & $74.05 \pm 1.48 \mathrm{abc}$ \\
20 & $72.76 \pm 2.86$ & $73.58 \pm 3.30$ & $73.17 \pm 2.09 \mathrm{bc}$ \\
25 & $72.46 \pm 2.17$ & $73.36 \pm 2.73$ & $72.90 \pm 1.64 \mathrm{c}$ \\
Rata-rata & $73.97 \pm 1.69$ & $75.00 \pm 2.06$ & \\
\hline
\end{tabular}

Angka disertai huruf berbeda pada kolom yang sama menunjukkan perbedaan nyata $(\mathrm{P}<0.05)$.

Analisis ragam menunjukkan bahwa terdapat perbedaan kadar air yang nyata pada lama penyimpanan 0,5 , $10,15,20$, dan 25 jam terhadap daging dada ayam $(\mathrm{P}<0.05)$. Terjadi penurunan kadar air dari lama penyimpanan 0 jam hingga lama penyimpanan 25 jam. Penurunan kadar air disebabkan salah satunya karena perubahan $\mathrm{pH}$ yang terjadi pada daging dada ayam. Kadar air adalah jumlah air total yang terkandung dalam bahan dan merupakan komponen terbesar dari daging 74.4\% (Rose 1997). Penurunan $\mathrm{pH}$ postmortem akan menurunkan kadar air dalam miofibril dari $80 \%-60 \%$ dari total air yang terdapat dalam daging (Price dan Scweighert 1971). Mead (1984) juga mengatakan bahwa tingkat keasaman yang terjadi selama postmortem akan mempengaruhi jumlah air yang keluar dari daging. Usmiati (2009) menyatakan bahwa penurunan $\mathrm{pH}$ yang cepat berhubungan dengan denaturasi miosin yang menyebabkan penyusutan air yang besar.

\section{Aktivitas Air}

Hasil analisis ragam menunjukkan bahwa tidak ada perbedaan yang nyata antara interaksi perlakuan pertama yaitu pemberian konsentrasi bakteriosin plantarisin IIA1A5 $10 \%$ dan $0 \%$ dengan perlakuan kedua yaitu lama penyimpanan pada jam ke- $0,5,10,15,20$, dan 25 terhadap aktivitas air pada daging dada ayam. Hasil analisis ragam 
menunjukan bahwa terdapat perbedaan aktivitas air yang nyata antara penggunaan bakteriosin plantarisin IIA1A5 $10 \%$ dan $0 \%$ terhadap daging dada ayam $(\mathrm{P}<0.05)$. Aktivitas air pada perlakuan bakteriosin 10\% lebih tinggi dibandingkan dengan plantarisin 0\%. Hal ini karena, bakteriosin $10 \%$ yang disemprotkan terlebih dahulu diencerkan dengan aquabidest.

Nilai aktivitas air yang lebih tinggi pada bakteriosin $10 \%$ tidak menyebabkan pertumbuhan mikroorganisme yang lebih tinggi dibandingkan dengan bakteriosin $0 \%$. Hal ini sesuai dengan jumlah mikroba yang terdapat pada Tabel 1. Plantarisin dapat sebagai agen bakterisidal sehingga membunuh mikroorganisme yang tumbuh pada daging dada ayam (Tahara et al. 1996). Aktivitas air merupakan jumlah air bebas yang dapat digunakan oleh mikroba untuk pertumbuhannya (Rahayu dan Nurwitri 2011). Nilai $a_{w}$ yang tinggi pada daging dada ayam akan mempercepat pertumbuhan mikroorganisme. Nilai rataan aktivitas air daging ayam pada suhu ruang disajikan pada Tabel 5 .

Tabel 5. Nilai rataan aktivitas air daging ayam pada suhu ruang

\begin{tabular}{cccc}
\hline \multirow{2}{*}{$\begin{array}{c}\text { Lama } \\
\text { Penyimpanan } \\
\text { (jam) }\end{array}$} & \multicolumn{2}{c}{ Konsentrasi bakteriosin } & Rata-Rata \\
\cline { 2 - 3 } & $0 \%$ & $10 \%$ & \\
\hline 0 & $0.83 \pm 0.00$ & $0.86 \pm 0.01$ & $0.84 \pm 0.00$ \\
5 & $0.84 \pm 0.01$ & $0.86 \pm 0.01$ & $0.85 \pm 0.01$ \\
10 & $0.84 \pm 0.02$ & $0.85 \pm 0.01$ & $0.84 \pm 0.01$ \\
15 & $0.83 \pm 0.01$ & $0.86 \pm 0.00$ & $0.84 \pm 0.00$ \\
20 & $0.83 \pm 0.00$ & $0.86 \pm 0.01$ & $0.84 \pm 0.00$ \\
25 & $0.82 \pm 0.01$ & $0.86 \pm 0.01$ & $0.84 \pm 0.01$ \\
Rata-Rata & $0.83 \pm 0.00 \mathrm{~b}$ & $0.86 \pm 0.00 \mathrm{a}$ & \\
\hline
\end{tabular}

Angka disertai huruf berbeda pada baris yang sama menunjukkan perbedaan nyata $(\mathrm{P}<0.05)$.

Analisis ragam menunjukkan bahwa tidak ada perbedaan aktivitas air yang nyata pada lama penyimpanan $0,5,10,15,20$, dan 25 jam terhadap daging dada ayam $(\mathrm{P}<0.05)$. Nilai rata-rata $\mathrm{a}_{\mathrm{w}}$ pada jam ke-0 hingga jam ke25 stabil pada angka \pm 0.84 . Ditemukan penurunan aw dari jam ke-0 hingga jam ke-25 pada bakteriosin plantarisin $0 \%$ dan nilai aw yang stabil pada perlakuan plantarisin $10 \%$ dari jam ke-0 hingga jam ke-25. Penurunan nilai aw ini karena berdasarkan Lawrie (1985) bahwa semakin lama postmortem maka urat daging akan menyusut sehingga banyak air terlepas yang juga akan mempengaruhi ketersediaan air bebas dalam daging. Eskin (1990) menyatakan bahwa penurunan nilai $\mathrm{pH}$ menyebabkan terjadinya denaturasi protein. Tersedianya air bebas secara mekanik dihambat oleh membran seluler protein (Lakkonen 1973). Denaturasi protein ini menyebabkan air bebas yang dihambat oleh protein berkurang sehingga banyak air bebas yang terlepas.

Warris (1992) mengatakan bahwa nilai pH daging berpengaruh terhadap air yang keluar dari daging. Daging dengan nilai $\mathrm{pH}$ rendah mengakibatkan struktur protein mengkerut dan menyebabkan penekanan air untuk keluar dari daging menjadi besar. Semakin banyak air yang keluar dari daging maka kadar air dalam daging menjadi berkurang dan juga menurunkan ketersediaan air bebas dalam daging. Plantarisin dapat menghambat adanya kerusakan protein pada daging ayam sehingga nilai aktifitas air pada daging ayam dengan perlakuan plantarisin lebih stabil.

\section{Kualitas Organoleptik}

Uji organoleptik dilakukan pada daging mentah yang diberikan bakteriosin plantarisin IIA-1A5 10\% dan 0\%. Hasil pengujian ini disajikan pada Tabel 6. Hasil pengujian organoleptik menunjukkan bahwa selama penyimpanan, penilaian panelis terhadap warna, aroma, dan lendir pada daging dada ayam mengalami penurunan. Uji organoleptik pada penelitian ini yaitu uji mutu hedonik untuk mengetahui tingkat kualitas produk berdasar penilaian panelis (Smith et al. 2012).

Penurunan hasil organoleptik tersebut sebanding dengan hasil pengujian fisiko kimia dan total mikroba. Hasil pengujian organoleptik terhadap warna yaitu warna pada daging dada ayam perlakuan plantarisin 10\% lebih baik dari perlakuan plantarisin $0 \%$ selama penyimpanan jam ke-0 hingga jam ke-20. Pada jam ke-25 warna daging pada kedua perlakuan sama. Warna daging pada jam ke-20 pada perlakuan plantarisin $10 \%$ sama dengan perlakuan plantarisin $0 \%$ pada jam ke-15. Warna pada daging dada ayam dipengaruhi oleh $\mathrm{pH}$. Lama penyimpanan akan menurunkan $\mathrm{pH}$ postmortem dan menurunkan kadar air

Tabel 6. Kualitas organoleptik (mutu hedonik) terhadap daging ayam broiler yang diberi Plantarisin IIA-1A5 0\% dan $10 \%$

\begin{tabular}{cccc}
\hline Pengujian & $\begin{array}{c}\text { Lama } \\
\text { Penyimpanan } \\
\text { (jam) }\end{array}$ & \multicolumn{2}{c}{ Perlakuan } \\
\cline { 3 - 4 } Warna & 0 & $3.18 \pm 0.90$ & $4.20 \pm 0.6$ \\
& 5 & $2.60 \pm 0.84$ & $3.48 \pm 1.22$ \\
& 10 & $2.53 \pm 0.96$ & $3.38 \pm 1.29$ \\
& 15 & $2.35 \pm 0.83$ & $3.28 \pm 1.29$ \\
& 20 & $1.95 \pm 0.68$ & $2.45 \pm 0.90$ \\
Aroma & 25 & $1.35 \pm 0.48$ & $1.65 \pm 0.86$ \\
& 0 & $3.65 \pm 0.70$ & $4.18 \pm 0.59$ \\
& 5 & $2.80 \pm 0.94$ & $3.90 \pm 0.67$ \\
& 10 & $2.75 \pm 0.84$ & $3.35 \pm 0.70$ \\
& 15 & $2.30 \pm 0.65$ & $3.13 \pm 0.91$ \\
& 20 & $1.90 \pm 0.67$ & $2.13 \pm 0.77$ \\
& 25 & $1.75 \pm 0.44$ & $1.78 \pm 0.77$ \\
& 0 & $3.00 \pm 0.80$ & $4.30 \pm 0.82$ \\
& 5 & $2.58 \pm 0.81$ & $3.90 \pm 0.67$ \\
& 10 & $2.80 \pm 0.79$ & $3.58 \pm 1.06$ \\
& 15 & $2.58 \pm 0.75$ & $3.43 \pm 0.87$ \\
& 20 & $2.30 \pm 0.72$ & $2.65 \pm 0.58$ \\
& 25 & $1.80 \pm 0.61$ & $1.88 \pm 0.72$ \\
\hline
\end{tabular}

Mutu hedonik (kualitas produk berdasar penilaian panelis); tingkat kecerahan warna: 1:sangat pucat, 2: pucat, 3:agak pucat (putih), 4:agak cerah merah, 5:cerah kemerahan; tingkat aroma: 1: sangat amis, 2: amis, 3: agak amis, 4: tidak amis, 5: aroma khas daging; tingkat lendir: 1: sangat berlendir, 2: berlendir, 3:agak berlendir, 4: tidak berlendir, dan 5: sangat tidak berlendir. 
dalam miofibril dari $80 \%-60 \%$ dari total air yang terdapat dalam daging. Kadar air yang terlepas akan membawa kandungan mioglobin dan zat nutrisi lainnya sehingga warna menjadi semakin pucat di dalamnya (Price dan Scweighert 1971).

Hasil pengujian organoleptik terhadap aroma pada daging dada ayam menunjukkan penilaian panelis bahwa perlakuan bakteriosin 10\% lebih baik dibandingkan dengan perlakuan bakteriosin $0 \%$. Perlakuan bakteriosin 10\% mampu menjaga aroma daging ayam pada kondisi agak amis sampai jam ke-15 sedangkan pada bakteriosin $0 \%$ hanya sampai jam ke-10. Hal ini menandakan bakteriosin $10 \%$ dapat menghambat kerusakan daging ayam lebih lama dengan cara menahan pembentukan senyawa-senyawa berbau busuk dan dapat menjaga dari pemecahan protein oleh mikroorganisme. Daging ayam memiliki komponen asam lemak tak jenuh yang labil terhadap proses oksidasi. Masa penyimpanan dapat mempengaruhi aroma karena proses oksidasi, kontraksi dengan udara menyebabkan penguapan sehingga aroma berkurang bahkan semakin lama menimbulkan aroma busuk. Lemak akan menghasilkan komponen volatil pada saat dipanaskan dan akan keluar bersama uap. Hal ini sesuai dengan pendapat Soeparno (1992), bahwa bau dan daging banyak ditentukan oleh precursor yang larut dalam lemak serta pembebasan substansi atsiri (volatil) yang terdapat dalam daging. Adanya perubahan $\mathrm{pH}$ dan aktivitas mikroorganisme pada daging ayam menyebabkan dekomposisi protein yang merusak rantai pada protein sehingga menghasilkan senyawa berbau busuk. Kebusukan akibat kerusakan daging ditandai oleh terbentuknya senyawa-senyawa berbau busuk sperti aminia, $\mathrm{H} 2 \mathrm{~S}$, indolm dan amin yang merupakan hasil pemecahan protein oleh mikroorganisme (Luthana 2009).

Hasil pengujian organoleptik terhadap lendir pada daging dada ayam menunjukkan penilaian panelis bahwa perlakuan bakteriosin 10\% lebih baik dibandingkan dengan perlakuan bakteriosin $0 \%$. Perlakuan bakteriosin 10\% mampu mempertahankan kondisi ayam tanpa lendir sampai jam ke-20 sedangkan perlakuan bakteriosin $0 \%$ hanya dapat mempertahankan kondisi ayam tanpa lendir sampai jam ke15. Pada jam ke-25 ditemukan adanya lendir pada masingmasing perlakuan. Hal ini membuktikan bahwa plantarisin IIA-1A5 10\% mampu mempertahankan kualitas daging dada ayam hingga jam ke-20. Lendir disebabkan oleh adanya bakteri yang tumbuh pada daging ayam. Terjadinya lendir pada daging ayam karena tumbuhnya bakteri $L$. Viriden dan bakteri pembentuk lendir berwarna hijau yaitu Enterococcus dan Bacillus thermospacta. Adanya karbohidrat berupa dekstran dan eksopolisakarida pada daging ayam menyababkan kedua bakteri ini dapat tumbuh dan berkembang dan membentuk lendir pada daging dada ayam tersebut (Frazier dan Westhoff 1998).

\section{KESIMPULAN}

Pemberian bakteriosin 10\% mampu mempertahankan kondisi daging ayam lebih baik sampai 20 jam penyimpanan pada suhu ruang. Terjadi penurunan kualitas daging ayam pada perlakuan kontrol (bakteriosin 0\%) dilihat dari $\mathrm{pH}$, kadar air, aktivitas air, total mikroba dan uji organolepik meliputi warna, aroma, serta lendir.

\section{UCAPAN TERIMAKASIH}

Ucapan terimakasih kami sampaikan kepada Kementerian Riset, Teknologi, dan Pendidikan Tinggi Republik Indonesia, yang telah mendanai penelitian ini melalui kolaborasi Penelitian Riset Inovatif Produktif Komersial (RISPRO Komersial) LPDP dengan nomor kontrak: PRJ-28/LPDP/2019.

\section{DAFTAR PUSTAKA}

AOAC (Association Of Analytical Chemists). 1984. Official Methods of Analysis. Ed ke-8. Washington DC (US): Association of Official Analytical Chemists Inc.

AOAC (Association of Official Analtical Chemists). 2005. Official Method of Analysis 962.09. Volume ke1. Maryland (US): Association of Official Analytical Chemists Inc.

Arief, I. I. 2011. Characterization of indigenous lactic acid bacteria from beef as probiotik and identification by 16S rRNA gene sequencing [tesis]. Bogor (ID): Bogor Agricultural University.

Arief, I. I., C. Budiman, B. S. L. Jenie, E. Andreas, \& A. Yuneni. 2015. Plantarisin IIA-1A5 from Lactobacillus plantarum IIA-1A5 displays bactericidal activity against Staphylococcus aureus. Beneficial Microbes. 6: 603-613.

BAM (Bacteriological Analytical Manual). 2001. Aerobic Plate Count. New York (US): FDA Department of Health and Human Services.

BPOM (Badan Pengawas Obat dan Makanan). 2013. Peraturan Batas Maksimum Penggunaan Bahan Tambahan Pangan Pengawet. Jakarta (ID): Badan Pengawas Obat dan Makanan.

BSN (Badan Standardisasi Nasional). 2009. Standar Mutu Karkas dan Daging Ayam SNI- 3924- 2009. Jakarta (ID): Badan Standardisasi Nasional.

Buckle, K. A., R. A. Edwards, G. H. Fleet, \& M. Wooton. 1987. Ilmu Pangan. Terjemahan: $H$. Purnomo. Jakarta (ID): Universitas Indonesia Pr.

Cleveland, J., J. T. Montville, I. F. Nes, \& C. K. Chikindas. 2001. Bacteriocin: safe. natural antimicrobils for food preservation. International Journal of Food Microbiology. 71:1-20.

Eskin, N. A. M. 1990. Biochemistry of Foods. Ed ke-2. Canada (CA): Departement of Foods and Nutrition. The University of Manitoba.

Frazier, W. C., \& D. C. Westhoff. 1978. Food Microbiology. Ed ke- 4. New York (US): Mc Graw Hill Book Co Ltd.

Jawetz, E., J. L. Melnick, A. E. Adelberg, G. F. Brooks, J. S. Butel, L. N. Ornston. 1995. Mikrobiologi Kedokteran. Edisi ke-20 (Alih bahasa : Nugroho dan Maulany RF). Jakarta (ID): Penerbit Buku Kedokteran EGC. hal. 211.213.215.

Jelenikova, J., P. Pipek, \& L. Staruch. 2008. The influence of ante-mortem treatment on relationship between $\mathrm{pH}$ and tenderness of beef. J Meat Sci. 80: $870-874$. 
Kanmani, P., R. S. Kumar, N. Yuvaraj, Paari, V. Pattukumar, \& V. Arul. 2010. Comparison of antimicrobial activity of probiotic bacterium Streptococcus phocae P 180. Enterococcusfaecium MC 13 and Carnobacterium divergensagainst fish pathogen. World J Dairy \& Food Sci. 5: 145-151.

Lakkonen, E. 1973. Factors Affecting Tenderness During Heating of Meat. In Chishester CO. Mark EM and Stewart GF. Advances in Food Research. London (UK): Academic Pr.

Lawless, H. T., \& H. Heymann. 2010. Sensory Evaluation of Food Principles and Practices. New York (US): Springer.

Lawrie, R. A. 1985. Meat Science. New York (US):Pergamon Pr.

Luthana, Y. K. 2009. Identifikasi Sederhana Makanan. Jakarta (ID): Bharata Karya Aksara

Mataragas, M., E. H. Drosinos, \& J. Metaxopoulos. 2003. Antagonistic activity of lactic acid bacteria against Listeria monocytogenes in sliced cooked cured pork shoulder stored under vacuum or modified atmosphere at $4 \pm 2^{\circ} \mathrm{C}$. Food Microbiology. 20: 259-265.

Mead, G. C. 1984. Processing of Poultry. New York (US): Elsevier Applied Science.

Moll, G. N., W. N. Konnings, \& A. J. M. Driessen. 1999. Bacteriocins: mechanism of membrane insertion and pore formation. Antonie van Leeuwenhoek. 76:185198.

Ogunbawo, S. T., A. I. Sanni, \& A. A. Onilude. 2003. Characterization of bacteriocin produced by Lactobacillus plantarum F1 and Lactobacillus brevis OG1. Afr J Biotechnol. 2 :219-227.

Pearson, A. M., \& R. B. Young. 1989. Muscle and Meat Biochemistry. California (US): Academic Pr Inc.

Pratiwi, S. T. 2008. Mikrobiologi Farmasi. Jakarta (ID): Erlangga

Price, J. F., \& B. S. Schweiggert. 1971. The Science of Meat and Meat Products. Ed ke-3. New York (US): Michigan University.

Rahayu, W. P., \& C. C. Nurwitri. 2012. Mikrobiologi Pangan. Bogor (ID): IPB Press.

Rose, S. P. 1997. Principle of Poultry Science. New York (US): CAB International.

Ryan, K. J., J. J. Champoux, S. Falkow, J. J. Plonde, W. L. Drew, F. C. Neidhardt, C. G. Roy. 1994. Medical Microbiology An Introduction to Infectious Disease. Ed ke-3.Connecticut: Appleton \& Lange. p.254.

Savadogo, A., C. A. T. Outtara, I. H. N. Bassole, \& A. S. Traore. 2006. Bacteriocins and lactic acid bacteria - a minireview. Afr J Biotechnol. 5: 678-683.
Smith, G. L., G. R. Culp, \& Z. L. Carperter. 1978. Post mortem aging of carcases. Journal Food Science. 430 $: 823$.

Steel, R. G. D., \& J. H. Torrie. 1995. Principles and Prosedures of Statistic Biomedical Approach. Ed ke-3. Singapore (SG): McGraw Hill.

Soeparno. 1992. Ilmu dan Teknologi Daging. Yogyakarta (ID): UGM-Pr.

Soeparno. 1994. Ilmu dan Teknologi Daging. Yogyakarta (ID): UGM Pr

Suradi, K. 2008. Perubahan sifat fisik daging ayam broiler postmortem selama penyimpanan temperatur ruang [tesis]. Bandung (ID): Fakultas Peternakan Universitas Padjadjaran.

Suyono, \& Slamet. 2001. Buku Ajar Ilmu Penyakit Dalam. Jilid II. Edisi 3. Jakarta (ID): Balai Penerbit FKUI.

Tahara, T. M., C. Oshimura, K. Umezawa, \& Kanatani. 1996. Isolation partial characterization and mode of action acidocin J1132. a two-compound bacteriocin produced by Lactobacillus acidophilus JCM 1132. Appl Environ Microbiol. 62:892-897.

Todorov, S. D., M. B. Wachsman, H. Knoetze, M. Meincken, \& L. M. Dicks. 2005. An antibacterial and antiviral peptide produced by Enterococcus mundtiiST4V isolated from soy beans. Int J Antimicrob Agent. 25(6): 508-513.

Todorov, S. D., H. Nyati, M. Meincken, \& L. M. T. Dicks. 2007. Partial characterization of bacteriocin AMA-K produced by Lactobacillus plantarum AMA-K isolated from naturally fermented milk from Zimbabwe. J Food Control. 18(6): 656-664.

Usmiati, S., \& T. Marwati. 2007. Seleksi dan optimasi proses produksi bakteriosin dari Lactobacillus sp. J Pascapanen. 4(1): 27-47.

Usmiati, S. 2009. Pengawetan Daging Olahan dan Segar. Bogor (ID): Balai Besar Penelitian dan Pengembangan Pascapanen Pertanian

Usmiati, S. 2010. Pengawetan Daging Segar dan Olahan. Bogor (ID): Balai Besar Penelitian dan Pengembangan Pascapanen Pertanian

Warsa, U. C. 1994. Staphylococcus dalam Buku Ajar Mikrobiologi Kedokteran. Edisi Revisi. Jakarta (ID): Penerbit Binarupa Aksara. hal. 103-110.

Warris, F. G. 1992. Meat Science. New York (US): CABI Publishing.

Winarno, F. G. 1992. Kimia Pangan dan Gizi. Jakarta (ID): Gramedia Pustaka Utama. 